\title{
Toxicity, anti-lipid peroxidation, invitro and invivo evaluation of antioxidant activity of Annona muricata ethanol stem bark extract
}

\author{
Sanni Olakunle, Obidoa Onyechi, Omale James \\ Department of Biochemistry, Kogi State University, Anyigba, Nigeria
}

Email address:

james.omale123@yahoo.com (O. James)

\section{To cite this article:}

Sanni Olakunle, Obidoa Onyechi, Omale James. Toxicity, Anti-Lipid Peroxidation, Invitro and Invivo Evaluation of Antioxidant Activity of Annona Muricata Ethanol Stem Bark Extract. American Journal of Life Sciences. Vol. 2, No. 5, 2014, pp. 271-277.

doi: 10.11648/j.ajls.20140205.14

\begin{abstract}
The presence of natural antioxidant capacity in plants has been well documented world over. There is an increasing demand for natural antioxidant to replace synthetic additives in the food and pharmacologicals. The objective of this study is to evaluate the invivo antioxidant potential of ethanol extract of Annona muricata against $\mathrm{CCl}_{4}$. induced toxicity in rats as well as its invitro antioxidant effect and lipid peroxidation. The extract was prepared by cold maceration using absolute ethanol. The invitro antioxidant properties of the extract was determined using DPPH (2,2-diphenyl-1-picrylhdrazyl) radical and invivo antioxidant enzymes were assayed to evaluate the biological activities of the extract. The polyphenol content of the extract was determined and it contained alkaloids, tannin, flavonoids, phenol in appreciable amount. In the invivo studies, the animals were grouped into three (3) groups of 15 rats each. Group 1 served as control and received $1 \mathrm{ml} / \mathrm{kg}$ b.w of olive oil orally for 28 days. Group 2 rats were orally administered $1 \mathrm{ml} / \mathrm{kg} \mathrm{CCl}{ }_{4}$ mixed with olive oil (1:10) daily for 28 days while group 3 rats were administered $1 \mathrm{ml} / \mathrm{kg} \mathrm{CCl}{ }_{4}$ and $200 \mathrm{mg} / \mathrm{kg} \mathrm{b.w} \mathrm{of} \mathrm{Annona} \mathrm{muricata} \mathrm{stem} \mathrm{extract.} \mathrm{Three} \mathrm{of} \mathrm{the} \mathrm{rats} \mathrm{from} \mathrm{each}$ group were sacrificed on days $1,8,15,22$ and 28. The plant extract showed remarkable hepatoprotective and antioxidant activity against carbon tetrachloride $\left(\mathrm{CCl}_{4}\right)$ induced oxidative stress as revealed from serum enzyme markers. $\mathrm{CCl}_{4}$ induced a significant rise $(\mathrm{p}<0.001)$ in aspartate amino transferase (AST), alanine amino transferase (ALT), alkaline phosphatase (ALP) and MDA (malondialdehyde) level in the serum with a reduction in catalase activity. Treatment of rats with the plant extract $(200 \mathrm{mg} / \mathrm{kg} \mathrm{b.w})$ significantly altered both serum enzymes activities and oxidant levels to near normal against $\mathrm{CCl}_{4}$ - treated rats. The invivo and invitro rapid radical scavenging studies were positive for the stem bark extract. This study suggests that the possible mechanism of the exhibited biological activities of the extract may be due to free radical scavenging owing to the presence of polyphenols in the extract. The plant extract possesses, antioxidant, anti-lipid peroxidation effect and is hepatoprotective. These may be the rationale for its folkloric uses and pharmacological effects.
\end{abstract}

Keywords: Annona muricata, Antioxidant, DPPH (2,2-Diphenyl-1-Picrylhydrazyl), Wistar Rats, Invitro And Invivo

\section{Introduction}

The human body has a complex system of natural enzymatic and non-enzymatic antioxidant defenses which counteract the harmful effects of free radicals and other oxidants. Free radicals are responsible for causing a large number of diseases including cancer (Kinnula and Crapo, 2004), cardiovascular disease (Singh and Jialal, 2006), neural disorders (Sas et al., 2007), Alzheimer's disease (Smith et al., 2000), mild cognitive impairment (Guidi et al., 2006), Parkinson's disease (Bolton et al., 2000), alcohol induced liver disease (Arteel, 2003), ulcerative colitis (Ramakrishma et al., 1997), aging (Hyun et al., 2006) and atheroscterosis (Upston et al., 2003).

Over $50 \%$ of all modern clinical drugs are of natural product origin (Stuffness and Douros, 1982) and natural products play an important role in drug development programmes in the pharmaceutical industry (Baker et al., 1995). Herbal drugs have gained importance in recent years because of their efficacy and cost effectiveness. Thus, there is an increasing interest in the measurement and use of plant antioxidant for scientific research as well as industrial purposes. The antioxidant reactions involve multiple steps 
including the initiation, propagation, branching and termination of free radicals. Free radicals are created when cells use oxygen to generate energy. These by-products are generally reactive oxygen species (ROS) such as superoxide anion, hydroxyl radical and hydrogen peroxide that result from the cellular redox process. At low or moderate concentrations, ROS exert beneficial effects on cellular responses and immune function but at high levels, free radicals and oxidants generate oxidative stress, a deleterious process that can damage cell structures, including lipids, proteins, and DNA (Pham-Huy et al., 2008).

Protection against free radicals can be enhanced by ample intake of dietary antioxidants. Substantial evidence indicates that foods containing antioxidants and possibly in particular the antioxidant nutrients may be of major importance in disease prevention. There is, however, a growing consensus among scientists that a combination of antioxidants, rather than single entities, may be more effective over the long term. Antioxidants may be of great benefit in improving the quality of life by preventing or postponing the onset of degenerative diseases. In addition, they have a potential for substantial savings in the cost of health care delivery.

These antioxidants acts as free radical scavengers by preventing and repairing damages caused by ROS, and therefore can enhance the immune defense and lower the risk of cancer and other degenerative diseases (Pham-Huy et al., 2008).

Antioxidants have been reported to prevent oxidative damage caused by ROS by reacting with free radicals, chelating, and catalytic metals and also by acting as oxygen radical scavengers (Shahidi and Wanasundra, 1992; Buyukokuroglu et al., 2001). The antioxidant in biological system can be either enzymatic or non-enzymatic. The enzymatic antioxidants include catalase, superoxide dismutase, glutathione which catalyse neutralization of many types of free radicals (Jacob, 1995), while the non-enzymatic antioxidants include Vitamin $\mathrm{C}$, selenium, Vitamin E, carotenoids, and polyphenols.

There is growing evidence that antioxidants play a pivotal role in the prevention of heart disease, cancer, DNA degeneration, pulmonary disease, and neurological disorder (Percival, 1998).

Recently, there has been an upsurge of interest in the therapeutic potential of plants as antioxidants in reducing oxidative tissue injuries (Patel et al., 2010). Plants, herbs, and spice, rich in phenolic compounds like flavonoids, have been demonstrated to have anti-inflammatory, anti-allergic, anti-viral, anti-aging, and anti carcinogenic activities which can be attributed to their antioxidant properties (Agil et al., 2006).

In the continuation of the strategy of new drug discovery for the management of oxidative stress related diseases, the plant Annona muricata have been studied for its antioxidant activity and phytoconstituents.

Annona muricata belongs to the family Annonaceae. It is commonly called "Graviola or Soursop" in English and other various local names. A. muricata $L$ is indigenous to most of the world's tropical rainforest areas of South and North America as well as West African Countries like Nigeria, Ghana, Ivory Coast and Gambia (Harrison and Rhett, 2005). All parts of Annona muricata tree are used in natural medicine in the tropics including the stem bark, leaves, and root, fruit and fruit seeds. A. muricata $\mathrm{L}$ has been used as phyto-therapy for various ailments such as cancer, as broad spectrum internal and external anti microbial to treat bacterial and fungal infections, anti- helmintic etc. Other uses of the plant documented by traditional medicine practitioners are: antiviral, digestive stimulant, anti-malarial, vermifuge (Das et al., 1999).

Despite the wide use of this plant as medicinal plant all over the globe, the literature contains few reports of antioxidant activity. The present study is aimed at establishing the invitro and Invivo antioxidant potentials of the ethanol stem bark extract of Annona muricata, anti-lipid peroxidation effect as well as the relationship of the phytochemical content with antioxidant activity.

\section{Materials and Methods}

\subsection{Chemicals Used}

All chemicals and reagents used were of analytical grade procured from reputable companies. 2, 2 - Diphenyl-1Picrylhydrazyl (DPPH) was obtained from Sigma Aldrich Co., St. Louis, USA. Enzymes assay kits were obtained from Randox Laboratories Ltd, Crumlin, Co., Antrim, UK. Malondialdehyde (MDA) assay kit was obtained from Northwest Life Science Specialist, LLC Vancouver, USA. Ethanol (BDH).

\subsection{Plant Material}

The plant sample i.e. Annona muricata was collected from Anyigba town, Kogi State, Nigeria and was authenticated. The stem bark was removed and cleaned from dirt. It was dried under shade at room temperature for 3 weeks.

\subsection{Preparation of Extract}

The dried stem bark of $A$. muricata was powdered using mechanical blender and $100 \mathrm{~g}$ of the powdered sample was extracted using cold maceration with $1 \mathrm{~L}$ of absolute ethanol for 7 days. The extract solution was filtered through whatman filter paper No. 1. The extract was concentrated under reduced pressure (bath temperature $50^{\circ} \mathrm{C}$ ). The dried extract was stored in airtight container until used.

\subsection{Experimental Animals}

Albino rats of Wister strain, weighing between $200-230 \mathrm{~g}$ maintained on normal rat pellet and water ad libitum, were divided into 3 groups of 15 rats each. They were obtained from the Department of Zoology, University of Nigeria, Nsukka, and kept in the Animal House of the Biochemistry Department, Kogi State University, Anyigba. The animals were allowed to acclimatize for two weeks before the 
commencement of the experiment. The animals were kept in well-ventilated cages at room temperature and under natural light/darkness cycles. They were maintained in accordance with the recommendation of the Guide for the care and use of laboratory animals (DHHS, 1985).

The relevant authorities in the Department of Biochemistry, Kogi State University has approved the use of the animals for the purpose of the experiment.

\subsection{Phytochemical Screening}

Phytochemical screening was carried out with ethanol extract of the stem bark of $A$. muricata for the detection of various phytochemicals. The extract was tested for the presence of Tannins, Saponins, Glycosides, Alkaloids, Flavonoids, and Phenolic compounds using the standard procedures described by Trease and Evans, 2002.

\subsection{Determination of Physico-Chemical Properties}

The physico-chemical properties of $A$. muricata were determined following the method described by A.O.A.C (1999).

\subsection{Invitro Antioxidant Activity Studies}

\section{Reducing Power}

The reducing power was evaluated by method as described by Nabsree and Bratati (2007). Different concentrations of the extract $(25,50,75$ and $100 \mathrm{mg} / \mathrm{ml})$ were prepared in methanol. Sample solution $\left(03 \mathrm{ml}: 100 / \mathrm{gml}^{-1}\right)$ was mixed with reagent solution $(3 \mathrm{ml} ; 0.6 \mathrm{~m}$ sulphoric acid, $2.8 \mathrm{mM}$ sodium phosphate and $4 \mathrm{mM}$ Ammonium molybdate). A blank composed of $3 \mathrm{ml}$ of reagent solution and methanol was also prepared. All test tubes were capped and incubated in boiling water bath at $95^{\circ} \mathrm{C}$ for 90 minutes. Absorbances of samples were read against blank at $695 \mathrm{~nm}$. The antioxidant activity of sample was expressed as mg ascorbic acid equivalent.

\section{DPPH Free Radical Scavenging Activity}

The method described by Adesegun et al., 2008 was followed in the determination of DPPH radical scavenging activity of Annona muricata ethanol stem bark extract. Different concentrations of the extract $(25,50,75$, and 100 $\mathrm{mg} / \mathrm{ml}$ ) were prepared using methanol. $1 \mathrm{ml}$ of $0.002 \% \mathrm{DPPH}$ solution was mixed with $3 \mathrm{ml}$ of all the concentrations of the extract separately. The mixture was shaken vigorously and allowed to stand at room temperature in the dark for 20 minutes. The absorbance was read against blank at $577 \mathrm{~nm}$. Percentage scavenging activity was calculated using the expression.

$$
\begin{aligned}
& \% \text { Scavenging Activity } \\
& =\frac{\text { Absorbance control }- \text { Absorbance of sample }}{\text { Absorbance of control }} \times 100
\end{aligned}
$$

\subsection{Experimental Design/Animal Treatment}

Forty-five (45) rats weighing between 200-230g were sorted randomly into 3 groups of 15 rats each. Group 2 (control) received $1 \mathrm{ml} / \mathrm{kg}$ of olive oil orally throughout duration of the experiment, group 2 were administered orally $1 \mathrm{ml} / \mathrm{kg} \mathrm{CCl}{ }_{4}$ mixed with olive oil in ratio 1:10 daily while group 3 rats were given $1 \mathrm{ml} / \mathrm{kg} \mathrm{CCl}_{4}$ in same vehicle and then treated orally with $1 \mathrm{ml}(200 \mathrm{mg} / \mathrm{kg})$ of ethanol stem bark extract of $A$. muricata. Three (3) of the rats from each group were sacrificed on days $1,8,15,22$ and 28 .

\subsection{Preparation of Serum}

The animals were sacrificed by severing the jugular vein with a surgical blade. Blood was allowed to flow freely into plain bottles. The blood was allowed to clot and then centrifuged at $1500 \mathrm{x}$ g for five (5) minutes after which the serum was separated and used for enzyme assays.

\subsection{Biochemical Estimations}

\section{Estimation of Catalase Activity}

Catalase activity was estimated by determining the decomposition of $\mathrm{H}_{2} \mathrm{O}_{2}$ at $240 \mathrm{~nm}$ in an assay mixture containing phosphate buffer (Dhalwal et al., 2008). The change in absorbance/minute for each assay was calculated and the result expressed as CAT/Unit mg.

$$
\text { CAT }(\mathrm{U}) / 100 \mathrm{mg} \text { of sample }=\frac{\text { Absorbance } / \mathrm{min} \times 0.003}{38.3956 \times 10^{-6}}
$$

Estimation of Serum Aspartate Amino Trasferase (AST)

AST in serum was determined by the method of Tietz (1994).

Estimation of Alkaline Phosphatase (ALP)

ALP activity was estimated using the method described by Rosalki et al., 1993.

Estimation of Alanine amino trasferase (ALT). The determination of alanine amino transferase activity was carried out following the method of Friedman and Young, (1997).

\section{Estimation of Malondialdehyde (MDA).}

Measurement of the lipid peroxidation using MDA as marker was adopted and assayed following the procedure described by Botsoglou et al., 1994.

\subsection{Statistical Analysis}

Data analyses were run in triplicates. Data were transformed by analysis of variance (ANOVA). Statistical analysis was performed by the student's t-test and by ANOVA.

\section{Results}

\subsection{Phytochemical Investigation}

It was found that ethanol extract of the stem bark of $A$. muricata contained alkaloid, saponins, tannins, flavonoids, phenolic compounds and glucosides (Table 1). 
Table 1. Phytochemical Composition of A. muricata Stem Bark Extract

\begin{tabular}{ll}
\hline Phytochemical & Indication in Plant \\
\hline Alkaloid & ++ \\
Saponins & + \\
Tannins & ++ \\
Flavonoids & ++ \\
Phenolic compounds & +++ \\
Glycoside & + \\
\hline
\end{tabular}

Key: $+++=$ Presence of bioactive compound in very high concentration

$++=$ High concentration

$+=$ Presence of bioactive compound

$-=$ Absence of bioactive compound.

\subsection{Proximate Composition}

The proximate analysis revealed that the plant sample is low in mineral element (ASH, 8.5\%) and richer in carbohydrate $(50.79 \%)$ as presented in Table 2.

Table 2. Proximate Composition of A. muricata Ethanol Stem Bark Extract

\begin{tabular}{llllll}
\hline Moisture \% & Ash \% & $\begin{array}{l}\text { Crude } \\
\text { Fibre \% }\end{array}$ & Fat \% & Protein \% & Carbohydrate \% \\
\hline 13.26 & 8.5 & 13.20 & 6.0 & 8.31 & 50.79 \\
\hline
\end{tabular}

\subsection{Invitro Antioxidant Activity}

Table 3. DPPH Free Radical Scavenging Activity of A. muricata Ethanol Stem Bark Extract

\begin{tabular}{lllll}
\hline $\begin{array}{l}\text { Concentration } \\
\text { of Extract }\end{array}$ & $\mathbf{2 5} \boldsymbol{\mu g} / \mathbf{m l}$ & $\mathbf{5 0} \boldsymbol{\mu g} / \mathbf{m l}$ & $\mathbf{7 5} \boldsymbol{\mu g} / \mathbf{m l}$ & $\mathbf{1 0 0} \boldsymbol{\mu g} / \mathbf{m l}$ \\
\hline $\begin{array}{l}\text { Absorbance } \\
\% \text { Inhibition }\end{array}$ & $1.565 \pm 0.003$ & $1.318 \pm 0.004$ & $1.107 \pm 0.003$ & $1.015 \pm 0.003$ \\
\hline
\end{tabular}

Results are expressed as mean \pm S.D., $\mathrm{n}=3$.

In table 3 , the ethanol stem bark extract of $A$. muricata exhibited free radical scavenging activity in a concentration dependent fashion.

Table 4 shows the reducing power of $A$. muricata ethanol stem bark extract on molybdenum (vi). The absorbance increased with increase in concentration of the extract.

Table 4. Reducing Power of Annona muricata Ethanol Stem bark Extract on Molybdenum

\begin{tabular}{lllll}
\hline $\begin{array}{l}\text { Concentration } \\
\text { of Extract }\end{array}$ & $\mathbf{2 5} \boldsymbol{\mu g} / \mathbf{m l}$ & $\mathbf{5 0} \boldsymbol{\mu g} / \mathbf{m l}$ & $\mathbf{7 5} \boldsymbol{\mu g} / \mathbf{m l}$ & $\mathbf{1 0 0} \boldsymbol{\mu g} / \mathbf{m l}$ \\
\hline Absorbance & $0.044 \pm 0.004$ & $0.061 \pm 0.002$ & $0.074 \pm 0.003$ & $0.096 \pm 0.002$ \\
$\mathrm{Mg}^{\left(\mathrm{AAEg}^{-1}\right)}$ & 0.48 & 0.67 & 0.81 & 1.05 \\
\hline
\end{tabular}

Results are expressed as mean \pm S.D., $\mathrm{n}=3$.

Table 5. Effect of Annona muricata Ethanol Stem Bark Extract on Liver ALT Activity in $\mathrm{CCl}_{4}$ - Induced Oxidative Stress in Rats (U/L)

\begin{tabular}{llll}
\hline Days & Control & $\mathbf{C C l}_{\mathbf{4}}$ Treated Rats & Treated with AMESBE \\
\hline Day 0 & $64.35 \pm 0.78$ & $66.87 \pm 1.13$ & $66.03 \pm 0.68$ \\
Day 7 & $66.13 \pm 0.88$ & $70.35 \pm 0.66^{\mathrm{a}, \mathrm{b}}$ & $66.48 \pm 0.77^{\mathrm{c}}$ \\
Day 14 & $66.99 \pm 0.61$ & $98.42 \pm 1.28^{\mathrm{a}, \mathrm{b}}$ & $72.66 \pm 2.01^{\mathrm{c}}$ \\
Day 21 & $69.97 \pm 0.33$ & $126.95 \pm 2.4^{\mathrm{a}, \mathrm{b}}$ & $77.92 \pm 1.76^{\mathrm{d}}$ \\
Day 28 & $74.43 \pm 1.20$ & $159.99 \pm 1.64^{\mathrm{a}, \mathrm{b}}$ & $79.69 \pm 0.89$ \\
\hline
\end{tabular}

Results are expressed as mean \pm S.D., $\mathrm{n}=3$.

${ }^{\mathrm{a}} \mathrm{p}<0.001 \mathrm{Vs}$ control, ${ }^{\mathrm{b}} \mathrm{p}<0.001 \mathrm{Vs}$ AMESBE Treated, ${ }^{\mathrm{C}} \mathrm{p}<0.01 ;{ }^{\mathrm{d}} \mathrm{p}<0.05 \mathrm{Vs}$ control (AMESBE - Annona muricata Ethanol Stem Bark Extract).
There is significant different $(\mathrm{p}<0.001)$ between the values of ALT in the $\mathrm{CCl}_{4}$-induced oxidative stress group and that of the control and Annona muricata extract treated group (Table 5).

Table 6. Effect of A. muricata Ethanol Stem Bark Extract on Liver AST Activity in $\mathrm{CCl}_{4}$ - Induced Oxidative Stress in Rats (U/L)

\begin{tabular}{llll}
\hline Days & Control & $\mathbf{C C l}_{\mathbf{4}}$ Treated Rats & $\begin{array}{l}\text { Rat Treated with } \\
\text { AMESBE }\end{array}$ \\
\hline Day 0 & $98.23 \pm 0.001$ & $100.34 \pm 0.001$ & $99.07 \pm 0.002$ \\
Day 7 & $97.20 \pm 1.88$ & $112.90 \pm 2.42^{\mathrm{a}, \mathrm{b}}$ & $102.66 \pm 2.65^{\mathrm{c}}$ \\
Day 14 & $100.75 \pm 0.50$ & $140.15 \pm 0.36^{\mathrm{a}, \mathrm{b}}$ & $111.25 \pm 0.50^{\mathrm{c}}$ \\
Day 21 & $103.42 \pm 0.33$ & $171.83 \pm 1.86^{\mathrm{a}, \mathrm{b}}$ & $116.83 \pm 0.76^{\mathrm{c}}$ \\
Day 28 & $108.71 \pm 0.38$ & $195.50 \pm 1.34^{\mathrm{a}, \mathrm{b}}$ & $123.50 \pm 1.89$ \\
\hline
\end{tabular}

Results are expressed as mean \pm S.D., $\mathrm{n}=3$.

${ }^{\mathrm{a}} \mathrm{p}<0.001$ Vs control, ${ }^{\mathrm{b}} \mathrm{p}<0.001 \mathrm{Vs}$ AMESBE Treated, ${ }^{\mathrm{C}} \mathrm{p}<0.01 \mathrm{Vs}$ control.

As presented in Table 6, serum activity of AST was higher and significantly different in the Annona muricata treated group than in control animals in day 7 to 21 of the experiment, although there was no significant increase in day 28 compared with control value.

Table 7. Effect of Annona muricata Ethanol Stem Bark Extract on Liver ALP Activity in $\mathrm{CCl}_{4}$ - Induced Oxidative Stress in Rats (U/L)

\begin{tabular}{llll}
\hline Days & Control & $\mathbf{C C l}_{\mathbf{4}}$ Treated Rats & $\begin{array}{l}\text { Rat Treated with } \\
\text { AMESBE }\end{array}$ \\
\hline Day 0 & $121.05 \pm 0.82$ & $138.73 \pm 0.62$ & $134.05 \pm 1.70$ \\
Day 7 & $122.72 \pm 2.50$ & $159.72 \pm 0.31^{\mathrm{a}, \mathrm{b}}$ & $136.43 \pm 3.51^{\mathrm{c}}$ \\
Day 14 & $123.21 \pm 2.60$ & $183.26 \pm 2.08^{\mathrm{a}, \mathrm{b}}$ & $136.38 \pm 0.93^{\mathrm{c}}$ \\
Day 21 & $125.38 \pm 0.70$ & $198.46 \pm 0.55^{\mathrm{a}, \mathrm{b}}$ & $139.38 \pm 1.66^{\mathrm{d}}$ \\
Day 28 & $126.29 \pm 0.89$ & $222.72 \pm 2.67^{\mathrm{a}, \mathrm{b}}$ & $138.39 \pm 1.03$ \\
\hline
\end{tabular}

Results are expressed as mean \pm S.D., $\mathrm{n}=3$.

${ }^{\mathrm{a}} \mathrm{p}<0.001 \mathrm{Vs}$ control, ${ }^{\mathrm{b}} \mathrm{p}<0.001 \mathrm{Vs}$ AMESBE Treated, ${ }^{\mathrm{C}} \mathrm{p}<0.01 ;{ }^{\mathrm{d}} \mathrm{p}<0.05 \mathrm{Vs}$ control.

As presented in Table 7, ALP activity is markedly elevated in $\mathrm{CCl}_{4}$ treated animals, indicating liver damage. Serum activity of ALP was higher and significantly different in Annona muricata treated group than in control animals in day 7 to 21, although there was no significant increase in day 28 compared to the control value.

Table 8. Effect of Annona muricata Ethanol Stem Bark Extract on the Activity of Catalase in $\mathrm{CCl}_{4}$ - Intoxicated Rats (U/100 mg)

\begin{tabular}{llll}
\hline Days & Control & $\mathbf{C C l}_{4}$ Treated Rats & $\begin{array}{l}\text { Rat Treated with } \\
\text { AMESBE }\end{array}$ \\
\hline Day 0 & $23.69 \pm 0.13$ & $22.85 \pm 0.91$ & $23.50 \pm 0.25$ \\
Day 7 & $23.14 \pm 0.45$ & $21.72 \pm 1.06$ & $22.57 \pm 0.63$ \\
Day 14 & $23.78 \pm 0.73$ & $19.26 \pm 0.87^{\mathrm{a}, \mathrm{b}}$ & $21.64 \pm 0.74^{\mathrm{c}}$ \\
Day 21 & $24.05 \pm 2.31$ & $17.57 \pm 0.56^{\mathrm{a}, \mathrm{b}}$ & $20.53 \pm 1.31^{\mathrm{c}}$ \\
Day 28 & $23.83 \pm 1.01$ & $15.72 \pm 0.84^{\mathrm{a}, \mathrm{b}}$ & $20.47 \pm 1.21^{\mathrm{c}}$ \\
\hline
\end{tabular}

Results are expressed as mean \pm S.D., $\mathrm{n}=3$.

${ }^{\mathrm{a}} \mathrm{p}<0.001$ Vs control, ${ }^{\mathrm{b}} \mathrm{p}<0.001 \mathrm{Vs}$ AMESBE Treated, ${ }^{\mathrm{C}} \mathrm{p}<0.01 \mathrm{Vs}$ control.

As presented in Table $8, \mathrm{CCl}_{4}$ treatment caused a significant $(\mathrm{p}<0.001)$ decrease in the level of catalase. Treatment with $A$. muricata resulted in a significant increase in catalase activity when compared with $\mathrm{CCl}_{4}$ treated rats. 
Table 9. Effect of Annona muricata Ethanol Stem Bark Extract on Lipid Peroxidation (MDA) in $\mathrm{CCl}_{4}$ - Intoxicated Rats ( $\mu \mathrm{mol}$ of $\mathrm{MDA} / \mathrm{L}$ )

\begin{tabular}{llll}
\hline Days & Control & $\mathbf{C C l}_{4}$ Treated Rats & $\begin{array}{l}\text { Rat Administered } \\
\text { AMESBE }\end{array}$ \\
\hline Day 0 & $45.23 \pm 0.32$ & $46.21 \pm 0.52$ & $45.13 \pm 0.71$ \\
Day 7 & $45.35 \pm 0.17$ & $60.57 \pm 0.44^{\mathrm{a}, \mathrm{b}}$ & $51.68 \pm 0.40^{\mathrm{c}}$ \\
Day 14 & $46.07 \pm 0.05$ & $67.61 \pm 0.56^{\mathrm{a}, \mathrm{b}}$ & $53.89 \pm 0.71^{\mathrm{c}}$ \\
Day 21 & $46.52 \pm 0.25$ & $71.94 \pm 0.46^{\mathrm{a}, \mathrm{b}}$ & $54.58 \pm 0.45^{\mathrm{c}}$ \\
Day 28 & $46.76 \pm 0.05$ & $79.97 \pm 0.08^{\mathrm{a}, \mathrm{b}}$ & $56.08 \pm 0.87^{\mathrm{c}}$ \\
\hline
\end{tabular}

Results are expressed as mean \pm S.D., $\mathrm{n}=3$.

${ }^{\mathrm{a}} \mathrm{p}<0.001 \mathrm{Vs}$ control, ${ }^{\mathrm{b}} \mathrm{p}<0.001 \mathrm{Vs}$ AMESBE Treated, ${ }^{\mathrm{C}} \mathrm{p}<0.01 \mathrm{Vs}$ control.

Estimation of lipid peroxidation levels by thiobarbituric acid reaction showed a significant $(p<0.001)$ increase in the serum level of MDA (Table 9) of rats intoxicated with $\mathrm{CCl}_{4}$. Annona muricata significantly $(\mathrm{p}<0.001)$ prevented the increase in MDA and was brought to near normal.

\section{Discussion}

Virtually all plants have one or more phytochemical resident in their leaf, stem, root, fruit and flowers. Ethanol stem bark extract of $A$. muricata contains phytochemicals including tannins, flavonoids, saponins and alkaloids which are known to exhibit medicinal as well as physiological activities. Flavonoid are hydroxylated phenolic substances known to be synthesized by plants in response to microbial infection and they have been found to be anti-microbial substances against wide array of microorganisms invitro (Marjorie, 1996). They are also effective antioxidants and show strong anti-cancer activities (Okwu, 2004). The presence of these phytochemicals in A. muricata could be contributory to its antioxidant activity observed in this investigation. In the present experiment the order of increasing relative abundance of these phytochemical in the ethanol stem bark extract of A. muricata is Glycoside Saponin Alkaloid Flavonoid Total phenolic compounds (Table 1).

Traditional medicine all over the world is nowadays revalued by an extensive activity of research on different plant species and their therapeutic principles. Experimental evidence suggests that free radical and reactive oxygen species can be involved in a high number of diseases (Sajeesh et al., 2011). As plants produce a lot of antioxidants to control the oxidative stress caused by sunbeams and oxygen, they can represent a source of new compounds with antioxidant activity.

Antioxidants (free radical scavengers) are chemicals that interact with and neutralize free radicals, thus preventing them from causing cellular damage in the biological system (Diplock et al., 1998). The body makes some of the antioxidants it uses to neutralize free radicals. These antioxidants are called endogenous antioxidants. However, the body also relies on external sources, primarily the diet,to obtain the rest of the antioxidants it needs (Valko et al., 2007). These exogenous antioxidants are commonly called dietary antioxidants. Fruits, vegetables, and grains are rich sources of dietary antioxidants (Bouayed and Bohn, 2010).
The invitro antioxidant potential of AMESBE was assayed using DPPH photometric assay and reducing power assay, while the invivo antioxidant potential was evaluated using serum catalase activity, and malondialdehyde level assay.

DPPH is a stable free radical at room temperature and accepts an electron or hydrogen radical. The reduction capability of DPPH radicals was determined by decrease in its absorbance at $517 \mathrm{~nm}$, which is induced by antioxidant.

The significant decrease in DPPH radical was due to the scavenging activity of Annona muricata ethanol stem bark extract (AMESBE). The reducing power of AMESBE was based on the ability of the extract to reduce molybdenum (VI) to molybdenum (V). The invitro antioxidant assay of AMESBE revealed that it has a potent antioxidant activity. DPPH is generally used to monitor chemical reactions involving radicals, most notably antioxidant assay (Sharma and Bhat, 2009).

The antioxidant compounds neutralize the free radical character of DPPH by transferring either electrons or hydrogen atoms to DPPH (Naik et al., 2003), thereby changing the colour from purple to the yellow coloured stable diamagnetic molecule - diphenylpicrylhydrazine. The degree of discoloration indicates the scavenging potential of the extract or antioxidant in terms of hydrogen donating ability (Mosquera et al., 2007). The antioxidant activity of AMESBE observed in this study could be due to the presence of phenolic compounds detected in it.

Other antioxidants work against the molecules that form from radicals, destroying them before they can begin the domino effect that leads to oxidative damage. For example, certain enzymes in the body such as superoxide dismutase, work with other chemical to transform free radical into harmless molecules.

The invivo antioxidant assay showed that AMESBE increased the activity of serum catalase. Catalase is an ubiquitous enzyme that catalyzes the decomposition of hydrogen peroxide, a reactive oxygen species (ROS) which is a toxic product of both normal aerobic metabolism and pathogenic ROS production (Kohen and Nyska, 2002). The increased serum activities of catalase as observed in this investigation suggest that AMESBE has an invivo antioxidant activity and is capable of ameliorating the effect of ROS in biologic system (Bakirel et al., 2008).

ROS react with all biological substance; however, the most susceptible ones are polyunsaturated fatty acids. Reactions with these cell membrane constituents lead to lipid peroxidation (Bakirel et al., 2008). In this investigation, the level of MDA is used as a marker of lipid peroxidation (LPO). The increase in MDA level in serum of intoxicated rats by $\mathrm{CCl}_{4}$ suggests enhanced lipid peroxidation leading to tissue damage and failure of antioxidant defense mechanism to prevent formation of excessive free radicals. Treatment with AMESBE significantly reversed these changes (Table 9). Malondialdehyde is an endogenous genotoxic product of enzymatic and ROS - induced LPO whose adducts are known to exist in DNA isolated from healthy human being (Niedernhofer et al., 2003). 
In our study, the increase in the activity of catalase could lead to the inactivation of LPO reactions, hence decrease in MDA (Table 9).

Enzymes are used also as markers for toxicity. Tables 5, 6 and 7 showed the activities of such enzymes following administration of a toxicant $\left(\mathrm{CCl}_{4}\right)$ as against the herbal drug (AMESBE).

Administration of $\mathrm{CCl}_{4}$ caused a significant $(\mathrm{p}<0.001)$ elevation of enzyme level such as AST, ALP and ALT when compared with control. There was a significant $(\mathrm{p}<0.001)$ restoration of these enzymes levels on administration of AMESBE. The reversal of the increased serum enzymes in $\mathrm{CCl}_{4}$ - induced liver damage by AMESBE may be due to the prevention of the leakage of intracellular enzymes by its membrane stabilizing activity. This is in agreement with the commonly accepted view that serum levels of transaminases return to normal with the healing of hepatic parenchyma and the regeneration of hepatocytes (Thabrew and Joice, 1987).

\section{Conclusion}

Based on this study, we safely conclude that AMESBE possesses invitro and invivo antioxidant activity, and anti lipid peroxidation effect and may be employed in protecting tissue from oxidative stress. These may be the rationale behind some of its folkloric uses and also may be responsible for some of its pharmacologic effects.

\section{Acknowledgements}

We gratefully acknowledge the technical support of $\mathrm{Mr}$ Friday T. Emmanuel, Chief Technologist, Department of Biochemistry, Faculty of Medicine, Kogi State University, Anyigba.

\section{References}

[1] A.O.A.C. (1999). Official method of analysis, $13^{\text {th }}$ Edition, Association of Official Analytical Chemists, Washington D.C. $1-30$.

[2] Adesegun, S.A., Elechi, N.A., Coker, H.A. (2008). Antioxidant activities of methanol extract of Sapium elliticum. Pakistan Journal of Biological Science. 11: 453-457.

[3] Agil, F., Ahmad, I., Mehmood, Z. (2006). Antioxidant and free radical scavenging properties of twelve traditionally used Indian medicinal plants. Turkish Journal of Biology. 30(3): 177-183.

[4] Arteel, G.E. (2003). Oxidants and antioxidant in alcohol induced liver disease. Gastroenterol. 124, 778-790.

[5] Baker, J.T., Boris, R.P., Carte, B. (1995). Natural product drug discovery and development. New perspective on international collaboration. J. of Nat. Prod. 58: 1325-1357.

[6] Bakirel, T., Bakirel, U., Keles, O.U., Ulgen, S.G., Yardibi, H. (2008). Invivo assessment of anti-diabetic and antioxidant activities of rosemary (Rosmarius officialis) in alloxaninduced diabetic rabbits. Journal of Ethnopharmacology.
116(1): 64-73.

[7] Bolton, J.L., Trush, M.A., Penning, T.M., Dryhurst, G., Monks, T.J. (2000). Role of quinines in toxicology. Chem. Res. Toxicol. 13, 135-160.

[8] Botsoglou, N.A., Fletouris, D.J., Papageougiou, G.E., Vassilopoulous, U.N., Mantisa, A.J., Trakatellis, A.G. (1994). Rapid, sensitive and specific thiobarbiturio acid method for measuring lipid peroxidation in animal tissue, food and feedstuff samples. Agric. Food. Chem. 42: 1931-37.

[9] Bouayed, J., Bohn, T. (2010). Exogenous antioxidants double-edged swords in cellular redox state: Health beneficial effects at physiologic doses versus deleterious effects at high doses. Oxidative medicine and cellular longevity. 3(4): 228237.

[10] Buyukokuroglu, M.E., Gulcin, I., Oktay, M., Kufrevioglu, O.I. (2001). "Invitro antioxidant properties of dantrolene sodium" Pharmacological Research 44(6): 491-494.

[11] Das, S., Pal, S., Mujib, A., Dey, S. (1999). Biotechnology of medicinal plants, recent advances and potentials. $1^{\text {st }}$ Edition Vol. II UK 992 Publications. Hyderabad, 126-139.

[12] Dhalwal, K., Shinde, V.M., Namdeo, A.G., Mahadik, K.R. (2008). Antioxidant profile and HPTLC densitometric analysis of Umbelliferone and Psoralen in Aegle Marmelos. Pharm. Biol. 46: 266-272.

[13] DHHS (1985). Guide for the care and use of Laboratory Animals, Institute of Laboratory Animal Resources Commission on Life Sciences, National Research Council, National Academy Press, Washington, DC, USA.

[14] Diplock, A.T., Charleux, J.L., Crozier, G., (1998). Functional food science and defense against reactive oxidative. British Journal of Nutrition. 80(1): S 77 - S 112.

[15] Friedman, N., Young, D.S. (1997). Disease and clinical laboratory tests. $30^{\text {th }}$ Edition, AACC Press, London. 400 Pp.

[16] Guidi, I., Galimberti, D., Lonati, S., Novembrino, C., Bamonti, F., Tiriticco, M., Fenoglio, C., Venturelli, E., Baron, P., Bresolin, N. (2006). Oxidative imbalance in patients with mild cognitive impairment and Alzheimer's disease. Neurobiol. Aging. 27, 262-269.

[17] Harrison, M.B., Rhett, D. (2005). Figs and the diversity of tropical rainforest. Biosciences. 55(12): 1052-1064.

[18] Hyun, D.H., Hernandez, J.O., Mattson, M.P., Decabo, R. (2006). The plasma membrane redox system in aging. Aging Res. Rev. 5, 209-220.

[19] Ingh, U., Jialal, I. (2006). Oxidative stress and atherosclerosis. Pathophysiology. 13, 129-142.

[20] Jacob, R.A. (1995). Antioxidants, clinical nutrition insight. Advanced Nutrition, 1998.

[21] Kinnula, V.L., Crapo, J.D. (2004). Superoxide dismutases in malignant cells and human tumors. Free Radic. Biol. Med. 36, 718-744.

[22] Kohen, R., Nyska, A. (2002). Oxidation of biological systems: oxidative stress phenomena, antioxidants, redox reactions and methods for their quantification. Toxicologic Pathology. 30(6): 620-650. 
[23] Marjorie, C. (1996). Plant products as antimicrobial agents. Clinical Microbiology Review. 12: 564-582.

[24] Mosquera, M.O., Correa, Y.M., Buitrago, D.C. and Nino, J. (2007). Antioxidant activity of twenty five plants from Colombian biodiversity. Memorias do Instituto Oswaldo Cruz. 102(5): 631-634.

[25] Nabsree, D., Bratati, D. (2007). Antioxidant activity of some leafy vegetables of India: A comparative study. Food Chemistry. 1: 471-474.

[26] Naik, G.H., Priyadarsini, K.L., Satav, J.G. (2003). Comparative antioxidant activity of individual herbal components used in ayurvedic medicine. Phytochemistry. 63(1): 97-104.

[27] Niedernhofer, L.J., Daniels, J.S., Rouzer, C.A., Greene, R.E., Marnet, L.J. (2003). Malondialdehyde, a product of lipid peroxidation, is mutagenic in human cells. Journal of Biological Chemistry. 278(33): 31426-31433.

[28] Okwu, D.E. (2004). Phytochemicals and vitamin content of indigenous species Southeastern Nigeria. J. sustainable Agriculture and Environment. 6(1): 30-37.

[29] Patel, R.V., Patel, P.R., Kajal, S.S. (2010). “Antioxidant activity of some selected medicinal plants in western region of India". Advances in Biological Research. 4: 23-26.

[30] Pham-Huy, L.A., He, H., Pham-Huy, C. (2008). Free Radicals, Antioxidants in disease and health. Int. J. Biomed. Science 4(2): 89-96.

[31] Ramakrishma, B.S., Varghese, R., Jayakumar, S., Mathan, M., Balasubramanian, K.A. (1997). Circulating antioxidant in ulcerative colitis and their relationship to disease severity and activity. J. Gastroenterol. Hepatol. 12, 490-494.

[32] Rosalki, S.B., Foo, A., Burlina, A. (1993). Multicentre evaluation of Iso ALP testkit for measurement of bone alkaline phosphatase activity in serum and plasma. Clinical Chemistry, 39: 648-652.
[33] Sajeesh, T., Arunachalam, K., Parimelazhagan, T. (2011). Antioxidant and antipyretic studies on Pothos scandens $L$. Asian Pacific Journal of Tropical Medicine. 4(11): 889-899.

[34] Sas, K., Robotka, H., Toldi, J., Vecsi, L. (2007). Mitochondrial, metabolic disturbances, oxidative stress and kynurenine system, with focus on neurodegenerative disorders. J. Neurol. Sci. 257, 221-239.

[35] Shahidi, F., Wanasundara, P.K. (1992). "Phenolic antioxidants" critical reviews in food science and nutrition, 32(1): 67-103.

[36] Sharma, O.O., Bhat, T.K. (2009). DPPH antioxidant assay revisited. Food Chemistry. 113(4): 1202-1205.

[37] Smith, M.A., Rothkamp, C.A., Nunomura, A., Raina, A.K., Perry, G. (2000). Oxidative in Alzheimer's disease. Biochem. Biophys. Ada 1502, 139-144.

[38] Stuffuess, M., Dauros, J. (1982). Current status of NCL plant and animal product programme. J. of Nat. Prod. 45, 1-14.

[39] Thabrew, M., Joice, P. (1987). A comparative study of the efficacy of Pavetta indica and Osbeckia octanda in the treatment of liver dysfunction. Planta Medica. 53: 239-241.

[40] Tietz, N. (1994). Textbook of Clinical Chemistry. $3^{\text {rd }}$ Edition, W.B. Saunders Company, New York.

[41] Trease, G.E., and Evans, W.C. (2002). Pharmacognosy, W.B. Saunders, London, UK, $15^{\text {th }}$ Edition.

[42] Upston, J.M., Kritharides, L., Stocker, R. (2003). The role of Vitamin E in atheroscherosis. Prog. Lipid Res. 42, 405-422.

[43] Valko, M., Leibfritz, D., Moncol, J., Gronin, M.T.D., Mazur, M., Telser, J. (2007). Free radicals and antioxidants in normal physiological functions and human disease. International Journal of Biochemistry and Cell Biology. 39(1): 44-84. 